\title{
CA9 Gene
}

National Cancer Institute

\section{Source}

National Cancer Institute. CA9 Gene. NCI Thesaurus. Code C104050.

This gene may be involved in cell proliferation and transformation. 